\title{
Risk Factors and Resilience: The Case of Second Cycle Primary School Children in Wolaita Zone, Ethiopia
}

\author{
Mebratu Belete Beka (Correspondence author) \\ Lecturer of Psychology at Wolaita Sodo University, Ethiopia \\ Tel: 251-911-072-096 E-mail: mabubelete@gmail.com \\ Eshetu Genemo Daga \\ Lecturer of Psychology at Wolaita Sodo University, Ethiopia \\ Tel: 251-916-832-499 E-mail: shalomeet98@yahoo.com
}

\begin{abstract}
Ejigu Demeke Doboro
Lecturer of Psychology at Wolaita Sodo University, Ethiopia

Tel: 251-913-089-079 E-mail: demeejigu36@gmail.com
\end{abstract}

\section{Tesfatsion Dominiko}

Lecturer of Psychology at Wolaita Sodo University, Ethiopia

Tel: 251-912-119-680_E-mail: tesfadom11@yahoo.com

Received: January 9, 2014 Accepted: March 24, 2014 Published: July 5, 2014

doi:10.5296/jsss.v1i2.5920 URL: http://dx.doi.org/10.5296/jsss.v1i2.5920

\begin{abstract}
Though some studies have examined risk factors, protective factors and resilience among children by foreign researchers, no study as yet has been documented with regard to the above concerns in Wolaita community children. The major objectives of this study were examining variables which put children at risks and protective factors that help to buffer against risks and stressors in order to foster resilience among second cycle primary school children. With this regard, the study assessed 369 boys and girls in grades seven and eight.
\end{abstract}




\section{Macrothink

The independent t-test and ANOVA analysis indicated no statistically significant differences and effect of gender among boys and girls concerning vulnerability to risk factors and their success stories with regard to resilience respectively. The Pearson's $r$ computation showed positive significant relationship between parental educational status and overall resilience among other background variables. Moreover, the research yielded positive significant relationships among resilience components and overall resilience. Age of respondents found to have significant effect on their hardiness and resourcefulness among other resilience components and also the presence of siblings at home showed significant effect on children's resourcefulness. Further ANOVA analysis showed that parental educational and occupational statuses' significant effect on children's hardiness, purpose, overall resilience and hardiness, resourcefulness and overall resilience respectively. Lastly, regression analysis manifested that age of children and parental educational status found to be significant predictors of child resilience and vulnerability to risk factors. Among protective variables included in the study; parents, family, teachers and schools were found to be strong predictors of child resilience. The important implication of this research finding is while the research on risk and protective factors is important to guide practice and the way interventions are provided, always all the stakeholders should remember that risk, protection and resilience will vary depending on the individual child, family and their unique situation. What is a risk or a protective factor for one child will not necessarily be for the other.

Keywords: Resilience, Risk, Risk factors, Protective factors 


\section{Introduction}

Positive psychology is a flourishing field of psychology which encompasses the study of positive personality traits. Resilience is one of those traits. Many children in the world, especially in developing countries, are facing stressful situations and challenges such as poverty, divorce, homelessness, poor coping skills and the presence of domestic violence (physical, sexual or emotional abuse etc) that put them at risk (Grothberg, 1995).

Children exposed to a variety of adverse experiences can suffer long-term damage or negative psychological outcomes (Brooks, 1994). Yet, studies have demonstrated a diversity of responses to events, even within similar environments and conditions (Rutter, 1989; Masten, Best \& Garmezy, 1990; Hogan, Halpenny \& Greene, 2002). Outcomes vary because individuals differ in terms of their susceptibility to risk and because there may be protective mechanisms which reduce risk (Rutter, 1985; Kolvin, Miller, Scott, Gatzanie, \& Fleeting, 1990).

The occurrence of multiple difficulties is an important factor related to outcomes as is the meaning of events or situations for the individual (Brown \& Harris, 1978; Lazarus \& Folkman, 1984; Turner \& Lloyd, 1995). A single stress generally has little effect on a child but an accumulation of adversity greatly increases the likely negative impact (Rutter \& Quinton, 1977; Kolvin et al., 1990). In Rutter's (1979) study, the presence of two or three risk factors resulted in a fourfold increase in the rate of psychiatric disorder and exposure to more than four stressors produced a tenfold increase in distress.

Children are generally resilient even when faced with major stressful life events and difficulties (Garmezy, 1993) and the majority emerge from childhood as psychologically healthy and socially competent (Grotberg 1995; Kolvin et al., 1990). Even with the most severe stresses and adversities, it is unusual for more than half of all affected children to succumb to a maladaptive outcome (Rutter, 1979). Children's responses to stress vary over time and circumstances. In fact, children are capable of repeatedly altering their reactions to tension (Rutter, 1989). Resilience is influenced by protective features within the child's environment which ameliorate the impact of difficulties and/or help the child to develop a strong self-concept and thus resist stress (Rutter, 1987). Protective elements might also include positive events or turning points in people's lives such as educational success (Garmezy 1987).

Certain personality attributes, such as self-confidence and a sense of control over one's life, can also protect an individual from risk factors (Holahan \& Moos, 1987). Children with adverse temperamental features are more likely to be the target of parental criticism and hostility (Rutter, 1987). Resilient youngsters have a strong belief in their ability to control their environment and this might involve seeking affirmation outside the family (Werner \& Smith 1982). External locus of control, in combination with poor social support, increases the risk of developing psychological disorder (Dalgard \& Haheim, 1998) and the use of avoidant coping strategies has also been shown to be a significant risk factor (Vaillant, 1977; Moos \& Schaefer, 1984).

Social support is perhaps the best-documented factor associated with stress resistance and this may come from a variety of sources (Holahan \& Moos, 1987; Dalgard \& Haheim, 1998). 
DeWilde, Kienhorst, Diekstra and Wolters (1994) found that at-risk children reported a low level of support from their families. Support from teachers and peers is associated with high self-esteem (Cauce, Felner, \& Primavera 1982; Stone, Fitzgerald, \& Kinsella 1990). However, low academic achievement does not in itself result in a negative self-concept (Hayes \& Kernan, 2001). The neighbourhood one lives in can provide protection, or increase risk (Aneshensel \& Sucoff, 1996).

Trying to identify specific risk features for research purposes can be problematic because similar outcomes often arise from diverse risk factors and, conversely, comparable risk factors can lead to different outcomes (Magnusson, Stattin, \& Allen, 1985). The measurement of resilience is similarly challenging. Children may display competence in many areas of their lives yet still be vulnerable in less obvious, psychological terms (Luthar \& Zigler, 1991). Resilience is also likely to fluctuate over time as it is not a stable attribute of the individual but rather a function of the interaction between the individual and environmental influences (Herronkohl \& Egolf, 1994).

Personal history also influences coping (Garbarino, 1999). Children who have experienced approval, acceptance, and opportunities for mastery are far more likely to be resilient than those who have been subjected to humiliation, rejection, or failure. The literature points not just to children's own inner resources and competencies but also to their interpersonal relationships as essential factors mediating risk and resilience. Thus, the presence of at least one supportive adult can have an enormous impact on a child's resilience (Ressler, Boothby, \& Steinbock, 1988; Werner \& Smith, 1992). Family members and significant others can play a major role in helping children interpret, "process," and adjust to, or overcome, difficult life experiences (Dawes, 1992).

Acting as mentors, adults can provide models of and reinforcement for problem solving, motivation, and other coping skills (McCallin \& Fozzard, 1991; Punamaki, 1987; Richman \& Bowen, 1997; Turton, Straker, \& Mooza, 1990). Developmental psychology has long emphasized the early bonding between mother and infant and overall quality of nurture within the primary care giving unit as absolutely fundamental to well-being, especially in younger children. Today, however, it is increasingly recognized that in many societies the mother is only one of several caregivers and that, consequently, children's attachments may be quite dispersed (Mann, 2001).

The centrality of emotional attachment to and support from a significant reference person is revealed in its absence. In the late 1990s in Sierra Leone, children who were separated from their families following abduction by the rebel forces or whose parents had been killed or deserted them during the war faced many grave difficulties. Without a caring guardian to take their side, children expressed feelings of being branded and were susceptible to discrimination and hostility. Fostering by extended family members does not always resolve their problems, as one adolescent girl emphasized:

You have to be humble to the aunt and uncle and show them respect. You must not be proud. Because you don't have mother, you don't have father so you have no other choice but to be humble. If you do good things you never get praised-they always shout on you and put you down. (15-year-old girl, Makeni, Sierra Leone, quoted in Bernard, 1995) 
Not only do supportive relationships with family and non parental adults help to protect children from the negative effects of stressful situations, there is considerable evidence that social support from peers can greatly enhance children's resilience (Boyden et al., 2004). In this context, boys learn from a young age not only the importance of teamwork and cooperation but also how to provide material, emotional, and physical assistance to peers. In addition to the confidence they build in their own ability to confront future challenges, they learn to trust that they are not alone and that others can assist them in times of need. Positive peer relationships provide children with an arena of support outside the family in which they can experiment, develop attitudes, skills, and values, and learn to share, help, and nurture one another. These relationships become especially important during middle childhood and adolescence and both mitigate the negative effects of adversity and contribute to a child's sense of self-esteem.

Neighborhoods and institutions such as schools and organized community groups can supplement protective factors at the individual and family levels by providing a supportive context for children. In industrialized countries, the state is fundamental in this regard, aiding children through a range of interventions, including food subsidies, housing, and social insurance. Today specialized state-run institutions of childhood-child care and leisure centers, schools, and so on-complement the traditional roles and functions of the family. During crises, they may replace family altogether. In contrast, most poor countries do not have the resources for widespread state support to communities, families, or children living in adversity. Where high birth rates, early mortality, and educational wastage are pressing problems, birth spacing, health, and education services take priority over social services and welfare policies (Gibbs, 1994).

According to Gunnestad's Model of Resilience Development, given the multi-dimensional nature of resilience and its contextual specificity, it is challenging to identify universal indicators of whether a person is on a resilient trajectory. Protective factors that support a child to cope in difficult circumstances and to re-establish normal life include those within the child, in child's environment and the interaction between these factors. Intellect, physical robustness and emotional stability may be seen as the raw material for resilience. Rutter, Tizard and Whitmore (1970), say that when looking at the protective factors that constitute resilient processes we look at those that are manifested in his/her relationships and interactions with the wider world. Cole (1996) identified three broad sets of variables that have been found to operate as protective factors in stress-resistant children. These are:

- Individual protective factors (i.e. child characteristics, such as temperament, cognitive skills and positive responsiveness)

- Familial protective factors (i.e. families marked by warmth, cohesion and positive responsiveness) and

- Community protective factors (i.e. availability of external systems)

Resilience is not only an inner strength or capacity but also a "competence" to move forward after recovery. Resilience is being competent despite exposure to severe or chronic adversities. Competence may however, change over time. So the definition of competence for a child living with the family may not be the same as the definition of competence for a street 
child. Whether seen as one's inner strength or competence or both, a person is at the center of experience; his or her will to do and be something is emphasized as part of resilient character (Vanistendael, 1995).

Resilience is thus complex. It takes personal characteristics and environmental factors to create resiliency. Resilience does not just come from the person but it also draws on biological (temperament) and psychological (internal locus of control) characteristics of the person. Environmental factors including opportunities and atmospheres also play a significant role in fostering resilience in children (Banaag, 1997).

Ethiopia is one of the developing countries in the world despite multi-faceted challenges, especially in the issues related to children. According to different statistical reports concerning population structure of Ethiopia, youths and children posses the lion's share. Nowadays children of Ethiopia are not free from different challenges which hamper their future development in different aspects. Most of the children, especially in rural areas, are stricken by various economical, social, cultural and psychological risks. Hence, this study aims to examine different risk factors which put primary school children at risks, forward the relevance of protective factors for parents/family, teachers, schools and other stakeholders in order to enhance resiliency among vulnerable children despite adversity.

Based on the empirical information stated above, the following research questions are developed:

$\checkmark \quad$ Is there statistically significant difference among boys and girls in coping with life stressors, vulnerability and resilience?

$\checkmark$ Do parental occupational status and educational background predict and contribute to the development of resilience despite stressors among children?

$\checkmark$ Do supportive family environment encourage the child's effort to cope with life stressors?

$\checkmark$ Are there statistically significant relationships among respondents' socio-demographic variables, resilience factors and overall resilience?

$\checkmark \quad$ What are the factors which put children at risks and required intervention strategies to minimize stressors and foster resilience among vulnerable children in Wolaita Zone?

\section{Materials and Methods}

\subsection{Study Design}

The study employed mixed research approach (qualitative and quantitative analysis). The variables included in the study were pertinent to description, prediction than explanation.

\subsection{Study Area Description}

The area selected for study was Wolaita Zone. It is $384 \mathrm{~km}$ away to the South from the country's capital, Addis Ababa. This zone is one of the densely populated zones in SNNPR. People of Wolaita speak Wolaita Language, which is one of omotic language family spoken in South Ethiopia. Children comprise the majority of population and in turn vulnerable to different life stressors and challenges in the selected zone.

\subsection{Sampling Techniques and Participants}

Wolaita zone has 12 woredas and 3 administrative towns. The selection of woredas from this 
zone and further selection of primary schools from the selected woredas were done by employing simple random sampling technique (lottery method). The woredas selected for the study were Damot Sore, Damot Gale, Damot Pulasa, Boloso Sore, Sodo Zuria and Humbo. Seventeen primary schools were included in the study from the selected woredas. Representative sample selection of students from selected schools was also employed random sampling technique.

Table 1. Names of Woredas, Selected Primary Schools and Number of Students selected based on $\operatorname{Sex}(\mathrm{N}=369)$

\begin{tabular}{|c|c|c|c|c|}
\hline \multirow[t]{2}{*}{ No } & \multirow[t]{2}{*}{ Woreda } & \multirow[t]{2}{*}{ Schools } & \multicolumn{2}{|c|}{$\begin{array}{l}\text { Number of students } \\
\text { included based on sex }\end{array}$} \\
\hline & & & Male & Female \\
\hline \multirow[t]{4}{*}{1} & \multirow[t]{4}{*}{ Sodo Zuria } & Delbo Wegene Primary School & 12 & 14 \\
\hline & & Gulgula Primary School & 13 & 9 \\
\hline & & Bakulo Segno Primary School & 12 & 10 \\
\hline & & Bosa Kacha Primary School & 11 & 9 \\
\hline \multirow[t]{3}{*}{2} & \multirow[t]{3}{*}{ Damot Gale } & Gacheno Primary School & 11 & 13 \\
\hline & & Mokonnisa Primary School & 10 & 10 \\
\hline & & Ade Charake Primary School & 10 & 10 \\
\hline \multirow[t]{2}{*}{3} & \multirow[t]{2}{*}{ Bolosso Sore } & Himbecho Primary School & 10 & 14 \\
\hline & & Gara Godo Primary School & 10 & 10 \\
\hline \multirow[t]{3}{*}{4} & \multirow{3}{*}{$\begin{array}{l}\text { Damot } \\
\text { Pulassa }\end{array}$} & Konasa Pulassa Primary Pchool & 13 & 9 \\
\hline & & Zamine Wulisho Primary School & 11 & 9 \\
\hline & & Abota Ulto Primary School & 12 & 14 \\
\hline \multirow[t]{2}{*}{5} & \multirow[t]{2}{*}{ Damot Sore } & Gununo Primary School & 10 & 10 \\
\hline & & Warka Primary School & 10 & 10 \\
\hline \multirow[t]{3}{*}{6} & \multirow[t]{3}{*}{ Humbo } & Tabala Primary School & 12 & 10 \\
\hline & & Faracho Primary School & 10 & 14 \\
\hline & & Hobicha Primary School & 10 & 10 \\
\hline
\end{tabular}

\subsection{Tools}

Different tools were employed for different data sources.

A: Questionnaire- this tool measured children's risk factors, resilience components and overall resilience. The scale for resilience components was adapted. Before administering this tool for the final data collection, its reliability coefficient was calculated $(\alpha=0.78)$. The tool to 
measure child risk factors was developed by the principal investigator and its pilot test yielded reliability coefficient of 0.82 .

B: Interview- structured interview was conducted with selected parents, principals and teachers on range of issues related to child risk and resilience. On the other hand, semi-structured interview was conducted with some selected children to supplement data obtained through questionnaire. The validity and relevance of interview items were checked before administration.

C: Focus group discussion- the discussion was made with some selected respondents from all categories on issues related to risk factors and on how to foster resilience among vulnerable school children. The validity and relevance of focus group discussion items were assured before administering to respondents.

\subsection{Data Collection Procedure}

The subjects of the study were identified first and their consents assured before administering and collecting data. Assistant data collectors were trained on data collection procedures, research ethics, commitment and appropriate recording of data. After securing consent, the data was collected based on subjects' convenience.

\subsection{Data Analysis Methods}

Qualitative data analysis techniques were used to describe respondents' background variables. The Pearson Product Moment Correlation was employed to examine the association among background variables, resilience components (hardiness, optimism, resourcefulness and purpose) and overall resilience. To examine sex difference among children, independent $t$-test was computed. To analyze the degree of effect of risk factors on resilience components and overall resilience, ANOVA was employed and lastly, multiple regressions was computed to assess the extent of varying effects of each predictor variables and protective factors on overall resilience. The significance level of .05 was used.

\section{Results}

\subsection{Background Characteristics of Participants}

A total of 369 primary school children were participated in the study. The background variables of the study were sex, age, grade level, number of children at home, parental educational status and parental occupation. Table below shows participants' socio-demographic characteristics. 


\section{Al Macrothink}

Table 2. Participants' Background Information ( $\mathrm{N}=369)$

\begin{tabular}{|c|c|c|c|c|}
\hline No & Variables & Categories & Frequency & Percentage \\
\hline \multirow{2}{*}{1} & \multirow{2}{*}{ Sex } & M & 187 & 50.7 \\
\hline & & $\mathrm{F}$ & 182 & 49.3 \\
\hline \multirow{2}{*}{2} & \multirow{2}{*}{ Grade Level } & 7 & 137 & 37.1 \\
\hline & & 8 & 232 & 62.9 \\
\hline \multirow{3}{*}{3} & \multirow{3}{*}{ No. of children at home } & $2-4$ & 190 & 51.5 \\
\hline & & $5-8$ & 147 & 39.8 \\
\hline & & Above 8 & 32 & 8.7 \\
\hline \multirow{5}{*}{4} & \multirow{5}{*}{$\begin{array}{c}\text { Parental educational } \\
\text { status }\end{array}$} & Illiterate & 105 & 28.5 \\
\hline & & 1ry education completed & 144 & 39.0 \\
\hline & & 2 dry education completed & 41 & 11.1 \\
\hline & & Diploma holders & 24 & 6.5 \\
\hline & & Degree and above holders & 55 & 14.9 \\
\hline \multirow{4}{*}{5} & \multirow{4}{*}{ Parental occupation } & Farmer & 100 & 27.1 \\
\hline & & Private business & 168 & 45.5 \\
\hline & & Government employee & 80 & 21.7 \\
\hline & & Others & 21 & 5.7 \\
\hline
\end{tabular}

As depicted in the table above among the total respondents, 187 (50.7 percent) were males and the rest were females. It is also manifested in the table that the number of siblings at participant children's home in the range of 2-4 accounts higher (51.5 percent) followed by the number of children in the range of 5-8 (39.8 percent). Respondents included in the study were from different parental education statuses. Higher number of students was from parents who have completed primary education $(144,39$ percent) followed by parents who were illiterate $(105,28.5$ percent). Lastly, nearly half of the respondents' parents run private business (168, 45.5 percent) followed by farmers (100, 27.1 percent).

3.2 Bivariate Correlation among Background Variables, Resilience Components and Overall Resilience 
Table 3. Pearson $r$ computations among children's background characteristics, resilience components and overall resilience $(\mathrm{N}=369)$

\begin{tabular}{cccccccccccc}
\hline Variables & 2 & 3 & 4 & 5 & 6 & 7 & 8 & 9 & 10 & 11 \\
\hline 1. Sex & .211 & .027 & $.110^{*}$ & .190 & $.194^{*}$ & -.142 & -.180 & -.090 & -.083 & -.069 \\
2. Age & & .000 & .000 & .003 & .200 & $.179^{*}$ & -.096 & -.091 & $.156^{*}$ & $.204^{* *}$ \\
3. Grade level & & & .133 & .065 & -.008 & -.006 & -.056 & .051 & $.149^{*}$ & -.039 \\
4. No. of children at \\
home
\end{tabular}

As to the data indicated above, there is no significant relationship among socio-demographic variables, resilience components and overall resilience except for parents' educational status $(\mathrm{r}=.714, \mathrm{p}<0.01)$. However, inter-correlation among resilience factors and overall resilience showed positive relationships. Hardiness is found to be highly correlated with overall resilience $(\mathrm{r}=.756, \mathrm{p}<0.01)$ followed by purpose $(\mathrm{r}=.727, \mathrm{p}<0.01)$. In summary, parental educational status as a demographic variable has positive relationship with children's resilience.

\subsection{Sex Wise Comparison of Children With Regard To Their Resilience}

Table 4. Independent $t$-test computation on children's resilience $(\mathrm{N}=369)$

\begin{tabular}{cccccc}
\hline & \multicolumn{4}{c}{ Levene's Equality of variances } & \multicolumn{4}{c}{ Test for } & t-test for Equality of means \\
\cline { 2 - 6 } & $F$ & Sig. & $t$ & $d f$ & Sig. \\
\hline Hardiness & .014 & .906 & .274 & 376 & .187 \\
Optimism & 4.014 & .046 & .345 & 376 & .109 \\
Resourcefulness & .041 & .839 & 1.730 & 376 & .085 \\
Purpose & 5.051 & .025 & 1.607 & 376 & .730 \\
Overall resilience & 4.039 & .045 & 1.323 & 376 & .784 \\
\hline
\end{tabular}




\section{Macrothink

The present study did not show statistically significant difference among boy and girl second cycle primary school students concerning resilience components and overall resilience. It was assumed that boys were better than girls concerning resilience but the finding did not prove the assumption.

3.4 The Effects of Sex, Age, Grade Level, Number of Children (Siblings) at Home, Parental Educational Status and Parental Occupation on Resilience Components and Overall Resilience

The relationship among independent and outcome variable is computed earlier; hence the next important task is testing the effects of each predictor variables on outcome ones. With this regard, Analysis of Variance (ANOVA) is conducted to test resilience components and overall resilience taken as outcome variables while sex, age, grade level, number of siblings at home, parental educational status and parental occupation taken as predictor (independent) variables.

Table 5a. Summary of the effect of Children's sex on resilience components and overall resilience $(\mathrm{N}=369)$

\begin{tabular}{llllll}
\hline Variables & Sum of Squares & $d f$ & Mean Square & $F$ & Sig. \\
\hline Hardiness Between Groups & .733 & 1 & .733 & .075 & .784 \\
Within Groups & 3587.711 & 367 & 9.776 & & \\
Optimism Between Groups & 1.683 & 1 & 1.683 & .119 & .730 \\
Within Groups & 5176.973 & 367 & 14.106 & & \\
Resourcefulness Between Groups & 22.167 & 1 & 20.602 & 2.992 & .085 \\
Within Groups & 2719.058 & 367 & 8.011 & & \\
Purpose Between Groups & 20.602 & 1 & 22.167 & 2.992 & .110 \\
Within Groups & 2940.152 & 367 & 7.409 & & \\
Overall resilience Between Groups & 154.923 & 1 & 154.9238 & 1.751 & .187 \\
Within Groups & 32474.638 & 367 & 8.47 & & \\
\hline
\end{tabular}

Sex of children does not have effect on their resilience as it is true in independent t-test computation. It can be said that sex is not significant independent variable which makes difference among students to bounce back from life challenges, develop positive life experiences and inculcate the feeling of success among them. 
Table $5 b$. Summary of the effect of children's age on resilience components and overall resilience $(\mathrm{N}=369)$

\begin{tabular}{llllll}
\hline Variables & Sum of Squares & $d f$ & Mean Square & $F$ & Sig. \\
\hline Hardiness Between Groups & 212.032 & 6 & 35.339 & 3.789 & .000 \\
Within Groups & 3376.412 & 362 & 9.327 & & \\
Optimism Between Groups & 221.855 & 6 & 36.976 & 2.700 & .014 \\
Within Groups & 4956.801 & 362 & 13.693 & & \\
Resourcefulness Between Groups & 273.233 & 6 & 45.539 & 6.680 & .000 \\
Within Groups & 2467.992 & 362 & 6.818 & & \\
Purpose Between Groups & 144.558 & 6 & 24.093 & 3.097 & .006 \\
Within Groups & 2816.195 & 362 & 7.780 & & \\
Overall resilience Between Groups & 1624.797 & 6 & 270.808 & 3.162 & .005 \\
Within Groups & 31004.764 & 362 & 5.649 & & \\
\hline
\end{tabular}

As opposed to sex, age of students has significant effect on their hardiness and resourcefulness as components of resilience. In normal conditions, it is generally true that when age increases people become stronger psychologically to face adversity and develop true sense of life out of it and it is also true for resourcefulness. The current study approved this truth. However, the study did not show significant effect of age on optimism, purpose and overall resilience.

Table 5c. Summary of the effect of children's grade level on resilience components and overall resilience $(\mathrm{N}=369)$

\begin{tabular}{llllll}
\hline Variables & Sum of Squares & $d f$ & Mean Square & $F$ & Sig. \\
\hline Hardiness Between Groups & .121 & 1 & .121 & .573 & .450 \\
Within Groups & 3588.324 & 367 & 9.777 & & \\
Optimism Between Groups & 16.502 & 1 & 16.502 & 8.328 & .004 \\
Within Groups & 5162.154 & 367 & 14.066 & & \\
Resourcefulness Between Groups & 7.187 & 1 & 7.187 & .965 & .327 \\
Within Groups & 2734.038 & 367 & 7.450 & & \\
Purpose Between Groups & 65.696 & 1 & 65.696 & 1.173 & .279 \\
Within Groups & 2895.057 & 367 & 7.888 & & \\
Overall resilience Between Groups & 50.871 & 1 & 50.871 & .012 & .912 \\
Within Groups & 32578.690 & 367 & 88.770 & & \\
\hline
\end{tabular}

As to sex, grade level of students has no significant effect on each of resilience components 
and overall resilience.

Table $5 d$. Summary of the effect existence of more siblings at home on children's resilience components and overall resilience $(\mathrm{N}=369)$

\begin{tabular}{llllll}
\hline Variables & Sum of Squares & $d f$ & Mean Square & $F$ & Sig. \\
\hline Hardiness Between Groups & 15.897 & 2 & 7.948 & .814 & .444 \\
Within Groups & 3572.548 & 366 & 9.761 & & \\
Optimism Between Groups & 104.572 & 2 & 52.286 & 3.771 & .024 \\
Within Groups & 5074.084 & 366 & 13.864 & & \\
Resourcefulness Between Groups & 112.186 & 2 & 56.093 & 7.809 & .000 \\
Within Groups & 2629.039 & 366 & 7.183 & & \\
Purpose Between Groups & 45.559 & 2 & 22.779 & 2.860 & .059 \\
Within Groups & 2915.195 & 366 & 7.965 & & \\
Overall resilience Between Groups & 837.073 & 2 & 418.537 & 4.818 & .009 \\
Within Groups & 1792.488 & 366 & 86.865 & & \\
\hline
\end{tabular}

The existence of more number of siblings at home found to have significant effect on students' resourcefulness among other components of resilience. It has no effect the other three components and overall resilience as well. The existence of siblings at home helps students to be rich psychological stamina, positive attributes and competence over life challenges and adversities.

Table 5e. Summary of the effect of parental educational status on children's resilience components and overall resilience $(\mathrm{N}=369)$

\begin{tabular}{llllll}
\hline Variables & Sum of Squares & $d f$ & Mean Square & $F$ & Sig. \\
\hline Hardiness Between Groups & 1453.600 & 4 & 363.400 & 4.243 & .000 \\
Within Groups & 1175.961 & 364 & 85.648 & & \\
Optimism Between Groups & 344.233 & 4 & 86.058 & 9.972 & .006 \\
Within Groups & 2616.520 & 364 & 7.188 & & \\
Resourcefulness Between Groups & 96.929 & 4 & 24.232 & 3.336 & .011 \\
Within Groups & 2644.296 & 364 & 7.265 & & \\
Purpose Between Groups & 199.396 & 4 & 49.849 & 3.644 & .000 \\
Within Groups & 4979.260 & 364 & 13.679 & & \\
Overall resilience Between Groups & 361.977 & 4 & 90.494 & 7.209 & .000 \\
Within Groups & 3226.467 & 364 & 8.864 & & \\
\hline
\end{tabular}


As depicted in the table above, parental educational status has significant effect on two of resilience components (hardiness and purpose) and overall resilience as well. In other words, educational status of parents as an independent variable found to have an impact on children's purpose and hardiness. Even though parental educational status has no effect on optimism and resourcefulness, it has significant effect on overall resilience.

Table $5 f$. Summary of the effect of parental occupational status on children's resilience components and overall resilience $(\mathrm{N}=369)$

\begin{tabular}{llllll}
\hline Variables & Sum of Squares & $d f$ & Mean Square & $F$ & Sig. \\
\hline Hardiness Between Groups & 1942.910 & 3 & 647.637 & 7.703 & .000 \\
Within Groups & 3686.651 & 365 & 84.073 & & \\
Optimism Between Groups & 98.985 & 3 & 32.995 & 4.208 & .006 \\
Within Groups & 2861.769 & 365 & 7.840 & & \\
Resourcefulness Between Groups & 172.094 & 3 & 57.365 & 8.150 & .000 \\
Within Groups & 2569.131 & 365 & 7.039 & & \\
Purpose Between Groups & 120.446 & 3 & 40.149 & 2.897 & .035 \\
Within Groups & 5058.210 & 365 & 13.858 & & \\
Overall resilience Between Groups & 268.668 & 3 & 89.556 & 9.846 & .000 \\
Within Groups & 3319.777 & 365 & 9.095 & & \\
\hline
\end{tabular}

As depicted in the table above, parental occupational status has significant effect on two of resilience components (hardiness and resourcefulness) and overall resilience. In other words, occupational status of parents as an independent variable has impact on children's resourcefulness and hardiness. Even though parental occupational status has no effect on optimism and purpose, it has significant effect on overall resilience.

Regression Analysis of predictor variables across resilience

Table $6 a$. Regression Analysis Summary of children's socio-demographic variables on overall resilience $(\mathrm{N}=369)$

\begin{tabular}{ll}
\hline Multiple $\mathrm{R}=.290$ & $\mathrm{R}^{2}=.084$ \\
\hline Adjusted $=.069$ & Standard $=9.086$ \\
\hline
\end{tabular}

ANOVA Table

\begin{tabular}{llllll}
\hline & $D f$ & $S S$ & $M S$ & $F$ & Sig. \\
\hline Regression & 6 & 2744.371 & 457.395 & 5.540 & .000 \\
\hline Residual & 362 & 29885.190 & 82.556 & & \\
\hline
\end{tabular}


Variables in the equation

\begin{tabular}{llllll}
\hline Variables & $B$ & Std error & Beta & $t$ & Sig. \\
\hline Sex & -2.711 & 6.378 & -.144 & -2.738 & .006 \\
Age & -1.766 & .990 & -.235 & -4.194 & .000 \\
Grade level & -2.161 & .421 & -.111 & -2.119 & .035 \\
Number of siblings & -.338 & 1.020 & -.023 & -.435 & .664 \\
Parental education & .992 & .778 & .345 & 2.512 & .000 \\
Parental occupation & -.057 & .395 & -.005 & -.089 & .929 \\
Constant & 93.593 & 6.378 & & 14.675 & .000 \\
\hline
\end{tabular}

As shown in the regression summary table above, the regression model that included sex, age, grade level, number of siblings at home, parental education and parental occupation as socio-demographic variables contributed significantly to the prediction of overall resilience of children $(\mathrm{F}(6,362)=5.540, \mathrm{p}<.05)$ accounting for 8.4 percent variance. The remaining 91.6 percent was attributed to variables not included in the study. Age of children and parental educational status strongly contributed to the variance on the overall resilience $($ Beta $=-.235$, $\mathrm{t}=-4.194$ and $\mathrm{Beta}=.345, \mathrm{t}=2.512$ respectively).

Table 6b. Regression Analysis Summary of the role of parents, schools/teachers and community/neighborhood as protective factors on children's overall resilience $(\mathrm{N}=369)$

\begin{tabular}{ll}
\hline Multiple $\mathrm{R}=.204$ & $\mathrm{R}^{2}=0.42$ \\
\hline Adjusted $=.034$ & Standard $=9.255$ \\
\hline
\end{tabular}

ANOVA Table

\begin{tabular}{llllll}
\hline & $D f$ & $S S$ & $M S$ & $F$ & Sig. \\
\hline Regression & 3 & 1363.612 & 454.537 & 5.306 & .000 \\
\hline Residual & 365 & 31265.949 & 85.660 & & \\
\hline
\end{tabular}

Variables in the equation

\begin{tabular}{llllll}
\hline Variables & $B$ & Std error & Beta & $t$ & Sig. \\
\hline Parents/family & .097 & .095 & .504 & 1.016 & .000 \\
Schools/ Teachers & .521 & .148 & .204 & 3.513 & .000 \\
Community/Neighborhood & -.195 & .175 & -.064 & -1.116 & .265 \\
Constant & 56.145 & 3.529 & & 15.910 & .000 \\
\hline
\end{tabular}

Multiple regression analysis showed that protective factors such as parents/family, 
schools/teachers and community/neighborhood combined together added significantly to the prediction of children's overall resilience $(\mathrm{F}(3,365)=5.30, \mathrm{p}<.05)$ accounting for 42 percent of variance. The rest 58 percent was attributed for other predictor variables not included in the study. Among the protective variables included in the study, parents/family and schools/teachers had greatly contributed to the variance (Beta=.504, $\mathrm{t}=1.106, \mathrm{p}<.05$ and Beta $=204, \mathrm{t}=3.513, \mathrm{p}<.05$ respectively).

\section{Analysis of Interview and Focus Group Discussion Data}

As to the interview data, parents of children mostly engage in some of general meetings during the beginning, mid and end of academic year (29, 93.54 percent). They rarely engage in their children's academic issues $(2,16.46$ percent). As to educational psychology books, the task of teachers is not only teaching. However, the present study showed that primary school teachers are not extensively engaged in other professional duties rather than teaching. Specially, formal counseling and guidance service is never been practiced in all school teachers. Furthermore, school principals do not have formal way of communication towards parents on children's educational achievements and challenges.

Students forwarded many risks which hamper their educational success. Among the many risks stated poverty, workload at home, failure to understand learning problems by teachers and lack of conducive learning environment are the ones. In general, the school principals and teachers seem to be not abide by many other essential professional duties. To inculcate the feeling of success and foster resilience among school children, commitment and professional rendering of the services are greatly required from teachers, school principals and other stakeholders.

\section{Discussion}

The current study examined factors which put primary school children at risks and their resilience that make them successful despite adversity with regard to different variables. Furthermore, the study explored protective factors which may buffer or reduce the effects of risk variable(s) by strengthening internal psychological characteristics, such as child's self esteem, competence or his/her interpretations of the risk exposure. The independent $t$-test was computed to examine sex wise difference among boys and girls concerning vulnerability to risk factors and resilience. However, the present study finding did not show statistically significant difference among boys and girls with this regard. Hence, sex is found to be not the significant contributing variable for differences concerning susceptibility to risk factors and resilience among students.

Research findings in different corners of the world put forward varying output concerning resilience on the bases of gender which agree and contradict with the present research finding. For instance Garmezy (1985), states that the responses of children to stress and adversity will obviously be modified by their age and thus their capacity to understand the experience. Gender is found to be significant variable in different research works. Males are vulnerable in terms of developing conduct and behavioral difficulties and for offending (Kolvin et al., 1990). Males appear to be more vulnerable in certain situations (such as family discord) and boys are more likely than girls to develop emotional and behavioral difficulties in these circumstances (Rutter, 1987). 
This may be due to a number of factors. Hetherington, Cox and Cox (1982) found that parents were more likely to argue in front of their sons than their daughters. Maccoby and Jacklin's (1974) work indicates that boys are more likely to react to difficulties in a disruptive, aggressive way and that this is likely to elicit negative reactions from parents and others. There are also varying cultural expectations for males and females in society and similar behaviour by boys and girls can have different consequences (Stevenson, Hinde, \& Hinde, 1986). Males and females have different ways of channeling emotional difficulties, which is, according to Chodorow (1978), a product of their differential emotional development in childhood. Young boys, she says, learn early in life to restrict the expression of emotion and this tendency is socially reinforced as they develop. The result is that males often experience difficulties expressing problems as they grow older. Females on the other hand are more likely to express feelings and to have channels in place to do so (Duncombe \& Marsden, 1993).

Males and females have different ways of channeling emotional difficulties, which is, according to Brooks (1994), a product of their differential emotional development in childhood. Young boys learn early in life to restrict the expression of emotion and this tendency is socially reinforced as they develop. The result is that males often experience difficulties expressing problems as they grow older. Females on the other hand, are more likely to express feelings and to have channels in place to do so. However, the current research work did not yield any significance effect of gender on children's vulnerability to risk factors and resilience.

The Pearson's $r$ computation showed that parental educational status has positive correlation with children's overall resilience. Furthermore, the analysis showed that all resilience factors (such as hardiness, optimism, resourcefulness and purpose) were found to be positively correlated with overall resilience. With this regard, Cole (1996), stated that resilience factors are interrelated traits which facilitate the development of strategies for coping with stressful life events. The factors encompass commitment, a sense of meaning, purpose, and perseverance associated with one's existence, control, a sense of autonomy, endurance and the ability to influence one's own life course and challenge. These factors also include the perception of change as a normal aspect of life and as an opportunity for growth.

According to different research findings, resilient children are socially competent, have a positive self esteem and a sense of their own efficacy and ability, which may enhance their coping strategies and they are able to understand and express a wide range of emotions in a socially appropriate manner. ANOVA computation also showed that sex of children does not have effect on their resilience as it is true in the case of independent t-test computation. It can be said that sex is not significant independent variable which makes difference among students to bounce back from life challenges, develop positive life experiences and inculcate the feeling of success among them. On the contrary, certain research findings put forward the effect of gender on overall resilience and its components. Researchers like Ruther (1989), showed that resilient girls tend to display autonomy, independence, emotionally expressive, socially perceptive and nurturant. Furthermore, children's chronological age is found to have an effect on their hardiness and resourcefulness among other components of resilience. The responses of children to stress and adversity will obviously be modified by their age and thus 
their capacity to understand the experience (Garmezy, 1993). Furthermore, the great the number of siblings at home, the more effect on resourcefulness of children.

Moreover, further ANOVA analysis showed that parental educational status has significant effect on two of resilience components (hardiness and purpose) and overall resilience as well. According to the research work by Gibbs (1994) children from better educated parents are more likely to be resilient and successful in schools. On the contrary, children of uneducated families are vulnerable to risk factors and experience failure in their academic performance. Parental occupational status was also found to have significant effect on children's hardiness and resourcefulness as resilience components and overall resilience. Age of children and parental educational status predict susceptibility to risk factors and resilience development among children.

Regression analysis showed schools, teachers and parents are significant protective factors that shield children from risk factors and enhance their resilience. Parental involvement in their children education has come to be strong predictor of students' success in school performance. This finding tends to be true with others research works. Having a parent who is actively engaged in a child's education is important factor that can help children cope with the obstacles in their environment. Helping child with home work, paying close attention to school achievements and attending school and after school events can demonstrate the importance of education and perhaps improve a child's commitment to the school (Grothberg, 1995). Furthermore, most parents of resilient children make visits with teachers, attend parent-teacher association meetings, and making extra visits as necessary when their child's performance fell. In some cases, non parental adults such as mentors or older siblings also served as educational supports for resilient children, both formally and informally.

To Garmezy (1983) and Bernard (1995), schools are an important risk or protective feature in the child's life. School offers the possibility of academic and social success and factors that will influence the outcome include socio-economic and family background, the ability to learn and the school environment. It is recognized that attitudes to learning are shaped early and that academic success rests predominantly on a child's early knowledge of how to learn, as well as what is learned (Rutter, 2000).

Schools that foster student resilience have been found to emphasize academic learning and opportunity for all students, active student and parent involvement, and sensitivity to student diversity (Rutter, 1989). Socio-economic factors appear to have a significant effect on educational participation and achievement. Cole (1996) has described socio-economic background as a powerful determinant of progress through the educational system. The researcher found clear differences in academic achievement between disadvantaged and non-disadvantaged children of primary schools. At second level, the increased participation rate of children from unskilled and semi-skilled groups. The disadvantaged and semi-skilled children were found to be vulnerable to risk factors.

Teachers in primary schools of Wolaita zone lack skills and commitment to take care of children at schools. Teachers were not obliged to listen to different psychological needs of children despite classroom teaching. As to our observation, there were large number of children (average $=61$ ) within a classroom. However, according to different research findings, teachers were found to be strong protective factors for primary school children. For instance, 
Boyden (2004) found that, school community, especially teachers, can provide protective factors for children by conveying an attitude of compassion, respect and understanding for the student. A teacher who is the most frequently encountered positive role model outside the family and a caring relationship often develops between student and teacher. Teachers who offer trustworthiness, sincere interest, individual attention and use rituals and traditions to students in the classroom are often the determining factor for whether a child opens his or her mind to learn. According to Miller, (2007) teachers who bridge the gap between home and school and are sensitive to and knowledgeable of their students cultural and community heritages provide better learning environments, particularly for students from low socio-economic status backgrounds.

\section{Conclusions}

The conclusion is specific to the particular situation of students in the study area/site, so that the finding does not represent students in another place outside the selected study site/zone. However, there are some universal facts found in the previous studies which show similarities in behaviors of resilient children. Therefore, the conclusion is particular but with general truths specific to risk factors and resilience among primary school children in the Ethiopian context. The selected sample students for the study are the reflections of the general situations of other students in the study site (area) in terms of risk factors and resilience.

For interventions to effectively address the actual needs and concerns of children, this information must be grounded in both sound theory and appropriate empirical evidence from a broad range of settings. The existing research into risk and resilience in children confronting adversity goes some way toward addressing these requirements by stressing, for example, the significance of personal traits of the individual child, family circumstances, and peer and institutional support.

What at one point in history, in one setting, and for one child may be a hazard, at another time and in another setting and for a different child may be an important stimulus to learning and competence: The factors that mediate risk and resilience may have different effects in each child at different phases during that child's life. These new constructs should also aid understanding of the effects on children of different kinds of risks, because it cannot be assumed that boys and girls deal with individual or intrafamilial adversities in the same way as they cope with major societal upheavals.

The current study arrived at the following conclusions:

a) Among the background variables, parental education status was found to be strongly correlated with children's overall resilience.

b) Sex and grade level of respondents did not prove their significant effects on students' resilience and vulnerability to risk factors. The results indicated more similarities than differences between boys and girl students and also grade levels. Thus, measures taken to improve girls' resilience statuses should also be directed toward raising boys' resilience statuses.

c) Age of students was found to be influential factor on hardiness and resourcefulness of students among other resilience components. 
d) The presence of siblings at home found to be significant factor to make children resourceful with regard to facing demanding risk factors and foster resilience.

e) Parental educational status was found to have significant effect on children's hardiness and purpose among other components and overall resilience. On the other hand, parental occupational status was also found to have significant effect on hardiness, resourcefulness and overall resilience.

f) Age of children and parental education status were found to be significant predictors for fostering resilience and success despite adversities among children as background variables.

g) Resilience can be enhanced by encouraging positive environments within parents/families and schools/teachers to counteract risks in children's lives. Knowledge of risk, protection and resilience often informs the development of early intervention strategies aimed at preventing and buffering children from risk factors. The impact of risk and protective factors must be considered in relation to the developmental pathway. Clearly, some factors are associated with greater risks/benefits at specific transition points in developmental pathway. In other words, the effect of risk and protective factors may depend on both the nature of the problem experienced and the nature of child development. Knowledge of the evidence base regarding risk and protective factors during the developmental pathway is critical in designing effective interventions.

\section{Acknowledgements}

We forward our heartfelt thanks and appreciation to staff members in the department of psychology, Wolaita Sodo University for their assistance. We are indebted to thank the principals of selected primary schools in Wolaita Zone for their welcoming and cooperation in the administration of instruments and collection of the data. Finally, the collaboration of classroom teachers in the administration of tools and collection of the data was also unforgettable. We deserve a great appreciation for them.

\section{References}

Aneshensel, C., \& Sucoff, C. (1996). The neighborhood context of adolescent mental health. Journal of Health \& Social Behaviour, 37, 293-310. http://dx.doi.org/10.2307/2137258

Banaag, C. (1997). Resiliency: Stories found in the Philippine Streets. Manila: UNICEF.

Bauman , M. (2002). Fostering Resilience in Children. California: Sage Publishers.

Bernard, B. (1995). Fostering Resiliency in Kids: Protective Factors in Family, School and Community. Portland, OR: Northwest Regional Educational Library

Boyden, J., \& et al (2004). Children and Poverty. Part II. Voices of children: Experiences and perceptions from Belarus, Bolivia, Sierra Leone, India and Kenya (Children and Poverty Series). Richmond, VA: Christian Children's Fund.

Brooks, R. (1994). Children at risk: Fostering resilience and hope. American Journal of Orthopsychiatry, 64, 545-553. http://dx.doi.org/10.1037/h0079565 
Brown, G., W. \& Harris, T. (1978). Social Origins of Depression. London: Tavistock Publications.

Cauce, A. M., Felner, R. D., \& Primavera, J. (1982). Social support in high-risk adolescents: Structural components and adaptive impact. American Journal of Community Psychology, 10, 417-428. http://dx.doi.org/10.1007/BF00893980

Chodorow, N. (1978). The Reproduction of Mothering: Psychoanalysis and the Sociology of Gender. Berkeley California: University of California Press.

Cole, M. (1996). Cultural psychology: A once and future discipline. Cambridge, MA: Harvard University Press.

Dalgard, O. S., \& Haheim, L. L. (1998). Psychosocial risk factors and mortality: A prospective study with special focus on social support, social participation, and locus of control in Norway. Journal of Epidemiology \& Community Health, 52, 476-481. http://dx.doi.org/10.1136/jech.52.8.476

Dawes, A. (1992). Psychological discourse about political violence and its effects on children. Paper presented at the meeting of the Mental Health of Refugee Children Exposed to Violent Environments, Refugee Studies Programme, University of Oxford, Oxford, UK.

DeWilde, E. J., Kienhorst, I. C. W. M., Diekstra, R. F. W., \& Wolters, W. H. G. (1994). Social support, life events and behavioural characteristics of psychologically distressed adolescents at high risk for attempting suicide. Adolescence, 29, 49-60.

Duncombe, J., \& Marsden, D. (1993). Love and intimacy: The gender division of emotion and 'emotion work'. Sociology, 221-241. http://dx.doi.org/10.1177/0038038593027002003

Garbarino, J. (1999). What children can tell us about the trauma of forced migration? Seminar presented at the Refugee Studies Programme, University of Oxford, Oxford.

Garmezy, N. (1993). Children in Poverty: resilience despite risk. Psychiatry, 56, 127-36.

Garmezy, N. (1987). Stress, competence, and development: Continuities in the study of schizophrenic adults, children vulnerable to psychopathology, and the search for stress resistant children. American Journal of Orthopsychiatry, 57, 159-174. http://dx.doi.org/10.1111/j.1939-0025.1987.tb03526.x

Garmezy, N. (1985). Stress-resistant children: The search for protective factors. In J. E. Stevenson (Ed.). Recent Research in Developmental Psychopathology, Journal of Child Psychology and Psychiatry Book Supplement No. 4 (pp. 213-233). Oxford: Pergamon Press.

Garmezy, N. (1983). Stressors of Childhood. New York: McGraw-Hill.

Gibbs, S. (1994). Post-war social reconstruction in Mozambique: Reframing children's experience of trauma and healing. Disasters, 18(3), 268-276. http://dx.doi.org/10.1111/j.1467-7717.1994.tb00312.x 
Grothberg, H. (1995). A guide to promoting resilience in children: Strengthening the human spirit. The Bernard Van Leer Foundation. Retrieved on April 11, 2012, from http://www.resilnet.uiuc.edu/library/grotb95b.html\#appendix1

Hayes, N., \& Kernan, M. (2001). Seven years old: School experience in Ireland. Dublin: Dublin Institute of Technology.

Herrenkohl, R. C., \& Egolf, B. (1994). Resilient early school-age children from maltreating homes. American Journal of Orthopsychiatry, 64, 301-309. http://dx.doi.org/10.1037/h0079517

Hetherington, E. M., Cox, M., \& Cox, R. (1982). Effects of divorce on parents and children. In M. Lamb (Ed.) Nontraditional Families. (pp. 233-288). Hillsdale NJ: Lawrence Erlbaum.

Hogan, D., Halpenny, A. M., \& Greene, S. (2002). Children's Experiences of Parental Separation. Dublin: The Children's Research Centre, TCD.

Holahan, C. J., \& Moos, R. H. (1987). Risk, resistance and psychological distress: A longitudinal analysis with adults and children. Journal of Abnormal Psychology, 96, 3-13. http://dx.doi.org/10.1037/0021-843X.96.1.3

Kolvin, I., Miller, F. J. W., Scott, D. M., Gatzanie, S. R. M., \& Fleeting, M. (1990). Continuities of deprivation? The Newcastle 1000 Family Study. Aldershot, U.K.: Avebury.

Lazarus, R. S., \& Folkman, S. (1984). Stress, Appraisal and Coping. New York: Springer Publishing Company.

Luthar, S. S., \& Zigler, E. (1991). Vulnerability and Competence: A Review of Research on Resilience in Childhood. American Journal of Orthopsychiatry, 61, 6-22. http://dx.doi.org/10.1037/h0079218

Maccoby, E. E., \& Jacklin, C. N. (1974). The Psychology of Sex Differences. Stanford, CA: Stanford University Press.

Magnusson, D., Stattin, H., \& Allen, V. L. (1985). Biological maturation and social development: A longitudinal study of some adjustment processes from mid-adolescence to adulthood. Journal of Youth and Adolescence, 14, 267-283. http://dx.doi.org/10.1007/BF02089234

Mann, G. (2001). Networks of support: A literature review of care issues for separated children. Stockholm: Save the Children Sweden.

Masten, A. S., Best, K. M., \& Garmezy, N. (1990). Resilience and development: contributions from the study of children who overcome adversity. Development and Psychopathology, 2, 188-220. http://dx.doi.org/10.1017/S0954579400005812

McCallin, M., \& Fozzard, S. (1991). The impact of traumatic events on the psychosocial wellbeing of Mozambican refugee women and children. Geneva: International Catholic Child Bureau. 
Miller, R. (2007). Cumulative Harm: A Conceptual Overview. Melbourne: The Victorian Department of Human Services

Moos, R. H., \& Schaefer, J. A. (1984). The crisis of physical illness: An overview and conceptual approach. In R.H. Moos (Ed.), Coping with Physical Illness: New Perspectives, Vol. 1. (pp. 3- 25). New York: Plenum Press. http://dx.doi.org/10.1007/978-1-4684-4772-9

Punamaki, R. L. (1987). Content of and factors affecting coping modes among Palestinian children. Scandinavian Journal of Development Alternatives, 6(1), 86-98.

Ressler, E., Boothby, N., \& Steinbock, D. (1988). Unaccompanied children: Care and protection in wars, natural disasters, and refugee movements. New York: Oxford University Press.

Richard, M., Lerner M., \& Ann, E. (2003). Hand Book Psychology: Developmental Psychology, New Jersey: John Wiley \& Sons Inc.

Richman, J. M., \& Bowen, G. L. (1997). School failure: An ecological-interactionaldevelopmental perspective. In M. W. Fraser (Ed.), Risk and resilience in childhood (pp. 95-116). Washington: NASW Press.

Rutter, M., Tizard, J., \& Whitmore, K. (1970). Education, Health and Behaviour. London: Longman.

Rutter, M., \& Quinton, D. (1977). Psychiatric disorders: Ecological factors and concepts of causation. In H. McGurk (Ed.) Ecological Factors in Human Development (pp. 173-187). Amsterdam, Holland: North-Holland. http://dx.doi.org/10.1192/bjp.131.1.67

Rutter, M. (1979). Protective factors in children's responses to stress and disadvantage. In M. W. Kent \& J. E. Rolf (Eds.) Primary Prevention of Psychopathology, Vol. 3: Social Competence in Children (pp. 49-74). Hanover, NH: University Press of New England.

Rutter, M. (1985). Family and school influences on behavioral development. Journal of Child

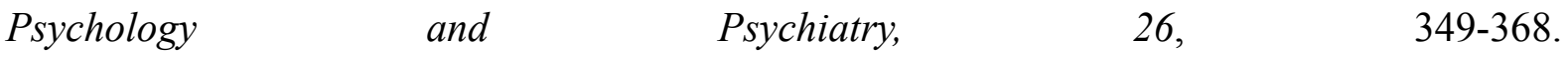
http://dx.doi.org/10.1111/j.1469-7610.1985.tb01938.x

Rutter, M. (1987). Psychosocial resilience and protective mechanisms. American Journal of Orthopsychiatry, 57, 316-331. http://dx.doi.org/10.1111/j.1939-0025.1987.tb03541.x

Rutter, M. (1989). Pathways from childhood to adult life. Journal of Child Psychology \& Psychiatry, 30, 23-51. http://dx.doi.org/10.1111/j.1469-7610.1989.tb00768.x

Rutter, M. (2000). Resilience Reconsidered: conceptual considerations, empirical findings and policy implications. Hand Book of Early Childhood Intervention. Cambridge: Cambridge University Press. http://dx.doi.org/10.1017/CBO9780511529320.030

Stevenson-Hinde, J. \& Hinde, R. A. (1986). Changes in associations between characteristics and interactions. In R. Plomin \& J. Dunn (Eds.) The Study of Temperament: Changes, Continuities and Challenges (pp.115-129). Hillsdale, NJ: Lawrence Erlbaum. 
Stone, D., Fitzgerald, M., \& Kinsella, A. (1990). A study of behavioural deviance and social difficulties in 11 and 12 year old school children. Irish Journal of Psychology, 11, 12-14.

Turton, R., Straker, G., \& Mooza, F. (1990). The experiences of violence in the lives of township youth in "unrest" and "normal" conditions. South African Journal of Psychology, 21(2), 77-84. http://dx.doi.org/10.1177/008124639102100201

Turner, R. J., \& Lloyd, D. A. (1995). Lifetime traumas and mental health: The significance of cumulative adversity. Journal of Health and Social Behaviour, 36(4), 360-376. http://dx.doi.org/10.2307/2137325

Vanistendael, S. (1995). Humor, Spirituality, and Resilience: The Smile of God, Geneva: ICCB Series.

Vaillant, G. E. (1977). Adaptation to Life. Boston: Little, Brown \& Co.

\section{Copyright Disclaimer}

Copyright reserved by the author(s).

This article is an open-access article distributed under the terms and conditions of the Creative Commons Attribution license (http://creativecommons.org/licenses/by/3.0/). 